\title{
PELUANG, TANTANGAN DAN STRATEGI PENGEMBANGAN UMKM DI INDONESIA PADA MASA PANDEMI COVID-19
}

Diajukan untuk memenuhi tugas pada mata kuliah Ekonomika Kerakyatan yang diampu oleh Bapak Ngadiyono, S.Pd., M.Pd.

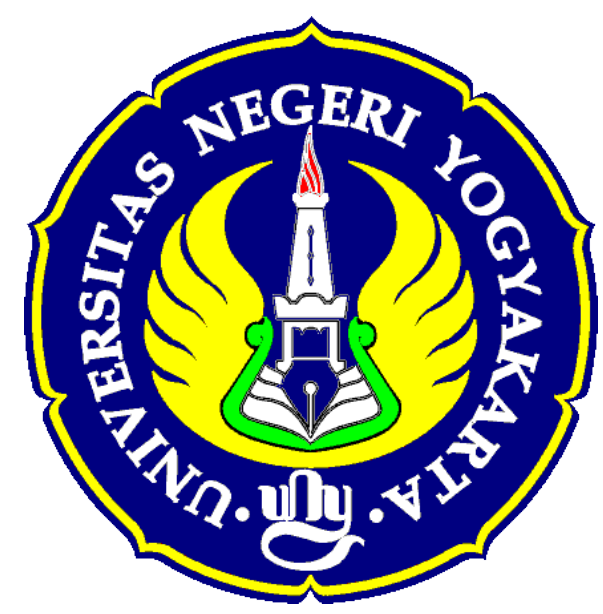

Oleh:

Indri Safitri (19804244029)

Pendidikan Ekonomi U 19

PENDIDIKAN EKONOMI

FAKULTAS EKONOMI

UNIVERSITAS NEGERI YOGYAKARTA 


\section{KATA PENGANTAR}

Assalamualaikum Wr. Wb

Puji syukur penulis panjatkan kehadirat Tuhan Yang Maha Esa yang telah melimpahkan rahmat, taufik dan hidayah-Nya sehingga penulis dapat menyelesaikan makalah yang berjudul "Peluang, Tantangan dan Strategi Pengembangan UMKM di Indonesia Pada Masa Pandemi COVID-19”. Makalah ini diajukan untuk memenuhi tugas pada mata kuliah Ekonomika Kerakyatan yang diampu oleh Bapak Ngadiyono, S.Pd., M.Pd.

Penulis mengucapkan terimakasih kepada semua pihak yang turut serta membantu dalam penyelesaian makalah ini baik dalam bentuk moril maupun materil. Sehingga, makalah ini dapat diselesaikan sesuai dengan waktunya.

Penulis menyadari bahwa dalam menyusun makalah ini masih jauh dari kesempurnaan, untuk itu kami sangat mengharapkan kritik dan saran yang bersifat membangun demi kesempurnaan makalah ini.

Akhir kata, penulis berharap agar makalah ini dapat memberikan informasi bagi masyarakat dan bermanfaat untuk pengembangan ilmu pengetahuan.

Wassalamualaikum Wr. Wb

Wonosobo, 8 Desember 2020

Hormat saya,

Penulis 


\section{DAFTAR ISI}

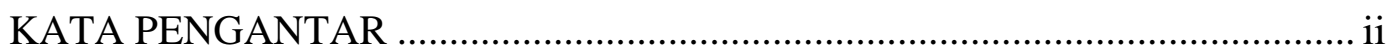

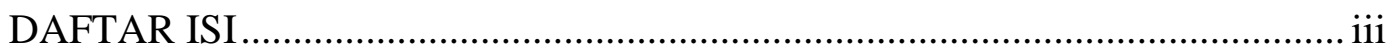

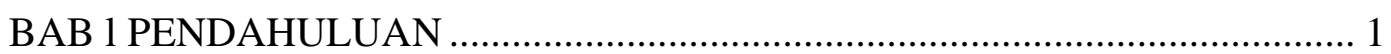

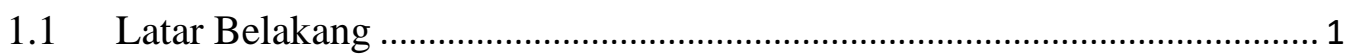

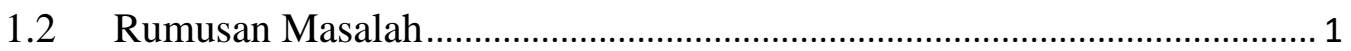

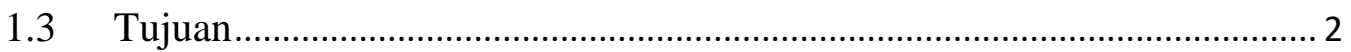

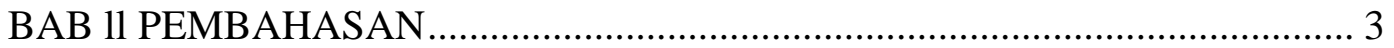

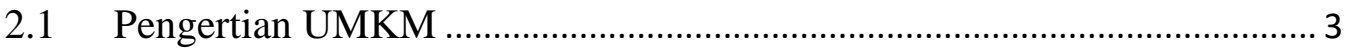

2.2 Karakteristik UMKM ........................................................................ 4

2.3 Asas dan Prinsip Pemberdayaan UMKM …........................................... 6

2.4 Tujuan Pemberdayaan UMKM ………................................................ 7

2.5 Peran UMKM dalam Perekonomian di Indonesia..................................... 8

2.6 Peluang Pengembangan UMKM di Indonesia Pada Masa Pandemi

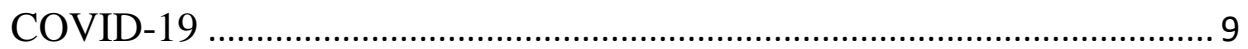

2.7 Tantangan dan Strategi Pengembangan UMKM di Indonesia Pada Masa

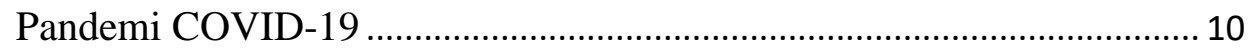

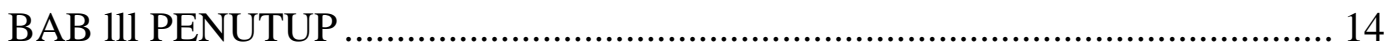

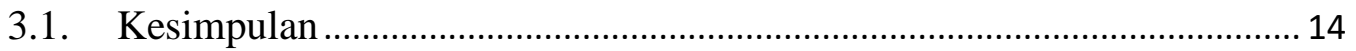

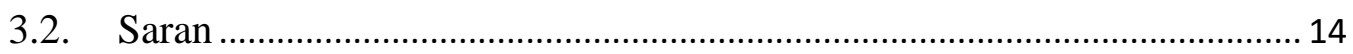

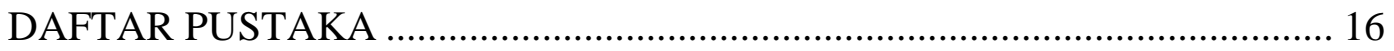




\section{BAB I \\ PENDAHULUAN}

\subsection{Latar Belakang}

Usaha Mikro, Kecil dan Menengah (UMKM) merupakan salah satu unit usaha yang berperan penting dalam pertumbuhan dan perkembangan perekonomian di Indonesia. UMKM juga merupakan salah satu penyokong perekonomian di Indonesia khususnya pada masyarakat golongan bawah dan menengah. UMKM memiliki peran strategis dalam upaya pemerintah dalam mengatasi kemiskinan dan pengangguran, karena UMKM dapat menyerap tenaga kerja sehingga pengangguran akibat tidak terserapnya angkatan kerja dalam dunia kerja menjadi berkurang.

Diawal tahun 2020, serangan pandemi COVID-19 telah memicu sentimen negatif terhadap berbagai lini bisnis khususnya bisnis UMKM. Dampak negatif akibat pandemi COVID-19 ini telah menghambat pertumbuhan UMKM. Indonesia yang didominasi oleh UMKM sebagai tulang punggung perekonomian nasional terdampak oleh adanya pandemi COVID-19, bukan hanya pada aspek produksi dan pendapatan saja, namun juga pada jumlah tenaga kerja yang harus dikurangi dan lain-lain. UMKM kurang memiliki ketahanan dan fleksibilitas dalam menghadapi pandemi COVID-19 ini dikarenakan beberapa hal seperti tingkat digitalisasi yang masih rendah, kesulitan dalam mengakses teknologi dan kurangnya pemahaman tentang strategi bertahan dalam bisnis.

\subsection{Rumusan Masalah}
a. Apa pengertian dari UMKM?
b. Bagaimana karakteristik dari UMKM?
c. Apa asas dan prinsip pemberdayaan UMKM?
d. Apa tujuan pemberdayaan UMKM?
e. Bagaimana peran UMKM dalam perekonomian di Indonesia? 
f. Bagaimana peluang pengembangan UMKM di Indonesia pada masa pandemi COVID-19?

g. Bagaimana tantangan dan strategi pengembangan UMKM di Indonesia pada masa pandemi COVID-19?

\subsection{Tujuan}
a. Untuk mengetahui pengertian dari UMKM.
b. Untuk mengetahui karakteristik dari UMKM.
c. Untuk mengetahui asas dan prinsip pemberdayaan UMKM.
d. Untuk mengetahui tujuan pemberdayaa UMKM.
e. Untuk mengetahui peran UMKM dalam perekonomian di Indonesia. pandemi COVID-19.
f. Untuk mengetahui peluang pengembangan UMKM di Indonesia pada masa
g. Untuk mengetahui tantangan dan strategi pengembangan UMKM di Indonesia pada masa pandemi COVID-19. 


\section{BAB Il \\ PEMBAHASAN}

\subsection{Pengertian UMKM}

Menurut Badan Pusat Statistik (BPS), usaha kecil merupakan usaha yang memiliki jumlah tenaga kerja 5 sampai dengan 19 orang, sedangkan usaha menengah merupakan usaha yang memiliki jumlah tenaga kerja 20 sampai dengan 99 orang.

Sesuai Undang-Undang Nomor 20 Tahun 2008 tentang Usaha Mikro, Kecil dan Menengah (UMKM) dijelaskan bahwa pengertian dari UMKM yaitu sebagai berikut:

a. Usaha Mikro adalah suatu usaha produktif milik orang perorangan dan/atau badan usaha perorangan yang memenuhi kriteria usaha mikro sebagaimana diatur dalam Undang-Undang ini. Usaha mikro memiliki kriteria asset maksimal sebesar Rp 50 juta dan omzet sebesar Rp 300 juta.

b. Usaha Kecil adalah suatu usaha produktif yang berdiri sendiri, yang dilakukan oleh orang perorangan atau badan usaha yang bukan merupakan anak perusahaan atau bukan cabang perusahaan yang dimiliki, dikuasai, atau menjadi bagian baik langsung maupun tidak langsung dari usaha menengah atau usaha besar yang memenuhi kriteria usaha kecil sebagaimana dimaksud dalam Undang-Undang ini. Usaha kecil memiliki kriteria asset sebesar Rp 50 juta sampai dengan Rp 500 juta dan omzet sebesar Rp 300 juta sampai dengan Rp 2,5 miliar.

c. Usaha Menengah adalah usaha ekonomi produktif yang berdiri sendiri, yang dilakukan oleh orang perorangan atau badan usaha yang bukan merupakan anak perusahaan atau cabang perusahaan yang dimiliki, dikuasai, atau menjadi bagian baik langsung maupun tidak langsung dengan usaha kecil atau usaha besar dengan jumlah kekayaan bersih atau hasil penjualan tahunan sebagaimana diatur dalam Undang-Undang ini. Usaha menengah memiliki 
kriteria asset sebesar Rp 500 juta sampai dengan Rp 10 miliar dan omzet sebesar Rp 2,5 miliar sampai dengan Rp 50 miliar.

\subsection{Karakteristik UMKM}

Berikut merupakan karakteristik atau ciri-ciri dari Usaha Mikro, Kecil dan Menengah (UMKM):

a. Jenis barang yang diproduksi dapat berganti sewaktu-waktu atau tidak tetap.

b. Tempat untuk melakukan kegiatan usaha dapat berpindah sewaktu-waktu

c. Dalam melakukan kegiatan usaha belum menerapkan administrasi, bahkan terkadang keuangan pribadi dan keuangan usaha masih disatukan.

d. Biasanya tingkat pendidikan sumber daya manusia dalam UMKM masih relatif rendah.

e. Pada umumnya pelaku usaha belum memiliki surat ijin usaha atau legalitas, termasuk NPWP.

Karakteristik atau ciri-ciri lain selain karakteristik di atas diantaranya yaitu:

a. Karakteristik Usaha Mikro

- Jenis barang yang dijual tidak tetap dan dapat berubah kapanpun.

- Tempat melakukan kegiatan usaha tidak menetap dan dapat berpindah sewaktu-waktu.

- Belum menerapkan administrasi keuangan dan masih menggabungkan keuangan pribadi atau keluarga dengan keuangan usaha.

- Tetap dapat berkembang meski negara mengalami krisis ekonomi.

- Tidak sensitif terhadap perubahan suku bunga.

- Sulit untuk mendapat bantuan kredit dari perbankan.

- Tenaga kerja yang dimiliki tidak banyak, sekitar 1 sampai 5 orang saja, termasuk juga anggota keluarganya.

- Usahanya juga relatif kecil.

- Lokasi usaha itu berada di lingkungan rumah. 
- Jarang terlibat dalam kegiatan atau aktivitas ekspor-impor.

- Manajemen usaha dilakukan sendiri secara sederhana.

b. Karakteristik Usaha Kecil

- Tidak mempunyai sistem pembukuan sehingga pelaku usaha sulit mendapat bantuan kredit dari perbankan.

- Sulit dalam meningkatkan atau memperbesar skala usaha, hal ini dikarenakan teknologi yang digunakan biasanya bersifat semi modern, bahkan masih ada yang mengerjakan usaha kecil dengan secara tradisional (tanpa teknologi).

- Tidak terlibat dalam kegiatan ekspor dan impor.

- Terbatasnya jumlah modal yang dimiliki.

- Pemilik usaha kecil tidak dapat membayar gaji pegawai apabila dalam jumlah yang besar.

- Biaya produksi per unit barang lebih tinggi.

- Jenis produk yang dijual tidak banyak. Usaha kecil dapat mengalami kebangkrutan apabila produk baru yang diproduksi tidak laku di pasaran atau produk lama yang sudah ketinggalan zaman.

- Kurang dapat dipercaya oleh masyarakat. Usaha kecil harus selalu berusaha myeakinkan masyarakat saat menawarkan produk baru. Masyarakat akan cenderung menerima produk dari perusahaan besar, karena produk dari perusahaan besar sudah memiliki image dan sudah dikenal oleh banyak orang di berbagai kalangan.

c. Karakteristik Usaha Menengah

- Memiliki manajemen usaha yang lebih baik dan lebih modern. Terdapat pembagian tugas yang jelas diberbagai bagian misalnya bagian produksi, bagian pemasaran, bagian keuangan, dll.

- Menerapkan administrasi keuangan dengan cara menggunakan sistem akuntansi secara teratur. Hal ini bertujuan untuk mempermudah pihak tertentu dalam melakukan pemeriksaan dan juga penilaian. 
- Memberikan jaminan sosial kepada para pekerja, misalnya jamsostek, jaminan kesehatan, dll.

- Memiliki berbagai persyaratan legalitas, misalnya izin tetangga, izin usaha, NPWP, izin tempat, dll.

\subsection{Asas dan Prinsip Pemberdayaan UMKM}

Berdasarkan Pasal 2 Undang-Undang Nomor 20 Tahun 2008, asas-asas pemberdayaan UMKM diantaranya yaitu sebagai berikut:

a. Asas Kekeluargaan

Yaitu asas yang melandasi upaya pemberdayaan UMKM sebagai bagian dari perekonomian nasional yang diselenggarakan berdasarkan demokrasi ekonomi dengan prinsip kebersamaan, keberlanjutan, efisiensi berkedilan, berwawasan lingkungan, kemandirian, keseimbangan, kemajuan dan kesatuan ekonomi nasional untuk tujuan tercapainya kesejahteraan rakyat.

b. Asas Demokrasi Ekonomi

Yaitu pemberdayaan Usaha Mikro, Kecil dan Menengah (UMKM) yang diselenggarakan sebagai kesatuan dari pembangunan perekonomian nasional untuk tujuan tercapainya kesejahteraan rakyat.

c. Asas Kebersamaan

Yaitu asas yang mendorong peran seluruh Usaha Mikro, Kecil dan Menengah (UMKM) dan dunia usaha secara bersama-sama dalam kegiatan untuk mewujudkan kesejahteraan rakyat.

d. Asas Efisiensi Berkeadilan

Yaitu asas yang mendasari pelaksanaan pemberdayaan Usaha Mikro, Kecil dan Menengah (UMKM) dengan mengedepankan efisiensi berkeadilan dalam usaha untuk mewujudkan iklim usaha yang kondusif, adil dan berdaya saing. 
e. Asas Berkelanjutan

Yaitu asas yang secara terencana mengupayakan berjalannya proses pembangunan melalui pemberdayaan UMKM yang membentuk perekonomian yang tangguh dan mandiri.

f. Asas Berwawasan Lingkungan

Yaitu asas yang dilakukan dengan tetap memperhatikan dan mengutamakan perlindungan serta pemeliharaan lingkungan hidup.

g. Asas Kemandirian

Yaitu asas yang dilakukan dengan tetap mengedepankan dan menjaga potensi, kemandirian dan kemampuan UMKM.

h. Asas Keseimbangan Kemajuan

Yaitu asas pemberdayaan UMKM yang berupaya menjaga keseimbangan kemajuan ekonomi wilayah dalam kesatuan ekonomi nasional.

i. Asas Kesatuan Ekonomi Nasional

Yaitu asas pemberdayaan UMKM yang merupakan bagian dari pembangunan kesatuan ekonomi nasional.

Menurut Bab II Pasal 4 Undang-Undang Nomor 20 Tahun 2008 tentang UMKM, prinsip pemberdayaan UMKM yaitu sebagai berikut:

a. Penumbuhan kemandirian, kebersamaan dan kewirausahaan UMKM untuk berkarya dengan prakarsa sendiri.

b. Pengembangan usaha berbasis potensi daerah dan berorientasi pasar sesuai dengan kompetensi UMKM.

c. Mewujudkan kebijakan publik yang transparan, akuntabel dan berkeadilan.

d. Peningkatan daya saing UMKM.

e. Penyelenggaraan perencanaan, pelaksanaan dan pengendalian secara terpadu.

\subsection{Tujuan Pemberdayaan UMKM}

Berdasarkan Bab II Pasal 5 Undang-Undang Nomor 20 Tahun 2008 tentang UMKM, tujuan dari pemberdayaan UMKM yaitu: 
a. Mewujudkan struktur perekonomian nasional yang seimbang, berkembang dan berkeadilan.

b. Menumbuhkan dan mengembangkan kemampuan UMKM menjadi usaha yang tangguh dan mandiri.

c. Meningkatkan peran UMKM dalam pembangunan daerah, penciptaan lapangan kerja, pemerataan pendapatan, pertumbuhan ekonomi dan pengentasan kemiskinan.

\subsection{Peran UMKM dalam Perekonomian di Indonesia}

Beberapa peran UMKM dalam perekonomian di Indonesia yaitu sebagai berikut:

a. Peran UMKM untuk Meratakan Perekonomian

Kehadiran UMKM dianggap mampu meratakan perekonomian di berbagai pelosok sehingga dapat tercapai kesejahteraan. Masyarakat di daerah terpencil dapat memenuhi kebutuhannya tanpa perlu mengunjungi kota besar. Apalagi jumlah total UMKM di Indonesia mencapai 99,9\% dari total unit usaha di Indonesia, sehingga UMKM memiliki peran besar dalam menyumbang perekonomian yang merata di Indonesia.

b. Peran UMKM untuk Mengurangi Kemiskinan

UMKM memberikan peluang bagi para pelaku usaha untuk membuka lapangan kerja baru. Penyerapan tenaga kerja yang tinggi bisa mengurangi kemiskinan sehingga berkurangnya angka pengangguran di Indonesia. Dari data UMKM yang dimiliki oleh Kementerian Koperasi dan Usaha Kecil dan Menengah, angka pertumbuhan pelaku UMKM selalu naik dari tahun ke tahun. Misalnya pada tahun 2018, UMKM mampu menyerap tenaga kerja kurang lebih hingga 120 juta orang. Ini menunjukkan sinyal bagus bagi tenaga kerja karena semakin terbuka lebarnya peluang.

c. Peran UMKM dalam Memberikan Devisa

Usaha kecil, mikro, dan menengah di Indonesia dinilai mampu menyumbang devisa bagi negara. Sumber-sumber devisa tersebut antara lain, 
adanya ekspor barang dan jasa ke negara lain serta kehadiran wisatawan asing yang berbelanja di dalam negeri.

\subsection{Peluang Pengembangan UMKM di Indonesia Pada Masa Pandemi COVID-19}

Peluang bisnis UMKM tidak terbatas meskipun pandemi COVID-19 telah membawa dampak negatif terhadap perkembangan UMKM. Pengembangan UMKM yang saat ini sudah berbasis digital dan begitu mudah diakses telah memicu banyak pergerakan ekonomi diberbagai pelosok daerah. Saat ini, potensi industri kreatif memiliki prospek dan peluang yang sangat menjanjikan. Apabila banyak industri kreatif yang terus digali dan ditingkatkan oleh UMKM maka daya serap ekonomi akan tersebar secara merata dan memiliki daya serap yang tinggi sehingga akan meningkatkan kemakmuran ekonomi di daerah tersebut serta akan menciptakan lapangan kerja baru agar dapat mengatasi kemiskinan.

UMKM memiliki peluang untuk tumbuh dalam masa pandemi COVID-19 dengan melakukan digitalisasi dan mengubah bisnis yang dilakukan sesuai dengan kebutuhan pasar. Dalam kondisi pandemi seperti ini, para pelaku UMKM harus mampu merespon perubahan-perubahan perilaku dan pola konsumen sebagai akibat dari adanya pandemi COVID-19. Pandemi COVID-19 telah memicu perubahan perilaku konsumen dimana pada kondisi seperti saat ini konsumen lebih memilih untuk belanja secara online.

Pembatasan Sosial Berskala Besar (PSBB) yang telah diterapkan oleh pemerintah selama masa pandemi COVID-19 harusnya dapat dimanfaatkan sebagai peluang untuk melakukan penjualan secara online. Pada bulan Maret 2020, Departemen Kebijakan Sistem Pembayaran Bank Indonesia mencatat transaksi pembelian melalui empat perdagangan elektronik di Indonesia mengalami peningkatan sebesar 18,1\% menjadi 98,3 juta transaksi. Total nilai transaksi pada pembelian ini juga bertumbuh hingga 9,9\% menjadi 20,9 triliun. Peningkatan transaksi terbesar adalah transaksi pada kebutuhan primer, yakni makanan dan minuman (52\%), perlengkapan sekolah (34\%) dan perawatan pribadi, seperti pensanitasi tangan dan masker (29\%). 
Perubahan perilaku konsumen dengan membatasi interaksi fisik dan mengurangi aktivitas yang dilakukan di luar rumah karena adanya penerapan Pembatasan Sosial Berskala Besar (PSBB). Hal ini tentunya memberi peluang yang besar kepada para pelaku UMKM khususnya UMKM yang sudah terhubung dengan ekosistem digital untuk bertahan atau bahkan melaju atau berkembang di tengah pandemi COVID-19. Kondisi di tengah pandemi COVID-19 seperti saat ini merupakan momentum yang tepat bagi Indonesia untuk melakukan percepatan digitalisasi UMKM.

\subsection{Tantangan dan Strategi Pengembangan UMKM di Indonesia Pada Masa Pandemi COVID-19}

Masa pandemi COVID-19 menjadi tantangan tersendiri bagi para pelaku UMKM. Tantangan UMKM di tengah pandemi COVID-19 diantaranya yaitu banyaknya para pelaku UMKM yang mengalami kesulitan untuk mendapatkan bahan baku karena diberlakukannya Pembatasan Sosial Berskala Besar (PSBB), banyak pelaku UMKM yang mengalami penurunan pendapatan akibat tidak adanya pelanggan yang membeli produk semenjak pemberlakuan PSBB dan physical distancing, pelaku UMKM mengalami kesulitan untuk mendapatkan pinjaman modal, serta anjloknya permintaan yang disebabkan karena terjadi ketidakpastian pasar yang akhirnya berdampak pada menurunnya permintaan akan barang dan jasa.

Di tengah pandemi COVID-19 seperti saat ini para pelaku UMKM harus bisa melakukan inovasi serta memanfaatkan kanal pemasaran dan penjualan online untuk menjaga keberlangsungan usaha. Selain itu para pelaku UMKM juga harus bisa menata ulang strategi bisnisnya. Dalam kondisi seperti saat ini, UMKM perlu melakukan penyesuaian diri dalam hal produk dan melakukan beberapa strategi pemasaran untuk bertahan. Terdapat beberapa hal yang dapat dilakukan oleh UMKM termasuk membuka lini produk baru dan memperbaharui sistem pemasaran yang ada, karena bisnis yang mampu bertahan yaitu bisnis yang responsif terhadap perubahan lingkungan. Beberapa hal yang dapat dilakukan oleh UMKM yaitu: 
a. E-commerce

Di tengah pandemi COVID-19 penjualan secara langsung umumnya mengalami penurunan yanng disebabkan oleh adanya penerapan PSBB sehingga masyarakat lebih memilih untuk berdiam diri di rumah. Menanggapi hal tersebut, salah satu cara yang dapat dilakukan yaitu dengan memperluas jaringan dengan memanfaatkan penjualan e-commerce sehingga UMKM tetap dapat menjalankan usaha dan menjangkau banyak konsumen serta memperluas pangsa pasar.

Di Era revolusi industri 4.0 para pelaku usaha UMKM memang sudah seharusnya bergerak ke perdagangan secara e-commerce karena pola pembelanjaan dari konsumen sudah bergeser, ditambah lagi dengan adanya pandemi COVID-19 yang menjadikan perdagangan e-commerce sebagai pilihan yang tepat untuk para pelaku UMKM untuk tetap bertahan bahkan memiliki potensi untuk dapat menjangkau pangsa pasar baru yang lebih besar.

b. Digital Marketing

Pandemi COVID-19 menyebabkan berkurangnya jumlah konsumen dibeberapa sektor dan industri, hal ini menuntut pelaku UMKM untuk dapat memasarkan produk secara maksimal dan memikirkan ide-ide kreatif dan inovatif. Semakin pesat perkembangan era digital seperti saat ini tidak mungkin untuk dihindari. Apalagi dimasa pandemi COVID-19 seperti saat ini apabila ingin tetap bertahan, maka UMKM harus mampu memaksimalkan manfaat dari perkembangan digital.

Terdapat beberapa bentuk digital marketing yang dapat dilakukan oleh UMKM untuk dapat melakukan pemasaran produk yaitu sebagai berikut:

- Melakukan publikasi video dan foto produk di sosial media secara intensif. Penggunaan sosial media ini perlu disesuaikan dengan segmen produk yang dimiliki.

- Membuat video produk pemasaran yang nantinya ditayangkan melalui sosial media atau melakukan live promosi produk. Strategi ini jika dilakukan dengan benar akan berpengaruh positif terhadap bisnis yang dijalani. 
- Melibatkan konsumen didalam pemilihan produk, melakukan edukasi dan pengenalan terhadap kualitas produk secara intensif di akun media sosial. Dengan hal ini nantinya terbentuk kesadaran merek dan dapat mempengaruhi keputusan pembelian konsumen.

Dalam melakukan digital marketing, pelaku UMKM dituntut untuk selalu belajar dan berfikir terbuka terhadap teknologi yang semakin berkembang. Tentunya pemasaran secara digital juga mempertimbangkan menggunakan media yang cocok dan cara komunikasi yang tepat yang disesuaikan dengan segmen atau pangsa pasar yang dipilih. Sehingga pemasaran akan lebih efektif dan tidak salah sasaran.

c. Memperbaiki Kualitas Produk dan Pelayanan

Ditengah Pandemi COVID-19, konsumen tentunya menjadi lebih berhati-hati dalam menggunakan barang dan jasa sehingga menyebabkan terjadinya penurunan kepercayaan konsumen terhadap barang dan jasa yang diperjualbelikan. Selain itu, keterbatasan konsumen dalam melakukan pembelian langsung juga berdampak pada berkurangnya jumlah pembelian konsumen secara signifikan. Untuk itu pelaku UMKM harus melakukan perbaikan kualitas produk untuk dapat meningkatkan kepercayaan konsumen dan secara intensif mengkomunikasikan terhadap kualitas produk. Sangat penting untuk UMKM untuk melakukan perbaikan kualitas produk secara berkala dengan menyesuaikan kebutuhan, keinginan dan harapan konsumen.

Selain peningkatkan kualitas produk, pelaku UMKM juga dapat meningkatkan kualitas pelayanan dan menambah jenis pelayanan seperti pesan antar dan pelayanan pembelian melalui online dan dengan menggunakan hotline layanan khusus terkait penjualan yang dapat dengan mudah diakses konsumen. Dalam melakukan pelayanan pesan antar, pelaku usaha harus lebih memperketat standar pelayanannya dengan meningkatkan dan memastikan kebersihan dari produknya. Untuk jasa, pelayanan bisa di kembangkan dengan melalui media online dan menggunakan aktifitas layanan daring sehingga bisa lebih efektif dan bisnis bisa berjalan seperti biasa. Pelayanan yang baik akan dapat membentuk kepercayaan konsumen sehingga dapat menciptakan 
kepuasan dan membentuk loyalitas konsumen. Pada masa pandemi COVID-19 seperti saat ini, kepercayaan konsumen menjadi salah satu faktor penting dalam keberlangsungan usaha.

\section{d. Customer Relationship Marketing (CRM)}

Pelaku UKM sebaiknya tidak hanya berfokus pada menjaring pelanggan baru saja tapi juga harus mempertahankan produk dan menjaga pelangan yang sudah ada serta menciptakan kepuasan pelanggan untuk menciptakan loyalitas pelanggan. Pelangan yang loyal tidak akan berpindah ke produsen lain karena sudah memiliki kepercayaan terhadap produk. Salah satu cara UMKM untuk dapat bertahan di tengah menurunnya geliat bisnis adalah dengan melakukan pemasaran hubungan pelanggan (customer relationship marketing). Customer relationship marketing adalah sebuah konsep strategi pemasaran yang berupaya menjalin hubungan jangka panjang dengan para pelanggan, yaitu mempertahankan hubungan yang kuat dan saling menguntungkan antara penyedia jasa dan pelanggan yang dapat membangun transaksi ulangan dan menciptakan loyalitas pelanggan.

Dalam kondisi seperti saat ini, untuk menjalin hubungan pemasaran dengan pelanggan dapat dilakukan dengan menunjukkan kepedulian terhadap konsumen yang sedang mengalami kesulitan pada saat COVID-19. Pelaku usaha dapat menunjukkan kepedulian yang juga bertujuan dalam memasarkan produk yang dimiliki. 


\section{BAB Ill \\ PENUTUP}

\subsection{Kesimpulan}

Pandemi COVID-19 yang terjadi di Indonesia berdampak pada ketidakstabilan dalam perekonomian terutama pada UMKM. Pelaku UMKM merasakan dampak langsung berupa penurunan omset penjualan dikarenakan adanya himbauan pemerintah dan penerapan PSBB yang menghimbau masyarakat untuk tetap dirumah sehingga cukup banyak UMKM yang harus berenti beroperasi untuk sementara waktu. Dalam kondisi seperti saat ini, bantak tantangan yang harus dihadapi oleh para pelaku UMKM. Untuk itu pelaku UMKM harus memiliki strategi untuk dapat bertahan di tengah pandemi ini dan dituntut untuk dapat menyesuaikan diri terhadap kondisi yang terjadi., sehingga dapat mengubah tantangan yang ada menjadi peluang.

Terdapat beberapa strategi yang dapat di lakukan UMKM untuk dapat mempertahankan bisnisnya, yaitu (1) melakukan penjualan melalui e-commerce. (2) Melakukan pemasaran produk dengan memanfaatkan teknologi digital (digital marketing). (3) melakukan perbaikan kualitas produk dan kualitas serta jenis layanan. (4) Melakukan pemasaran hubungan pelanggan (customer relationship marketing).

\subsection{Saran}

Saran yang dapat direkomendasikan adalah para pelaku UMKM harus memiliki strategi ataupun menerapkan strategi yang telah dijelaskan untuk dapat bertahan di tengah pandemi ini dan dituntut untuk dapat menyesuaikan diri terhadap kondisi yang terjadi., sehingga dapat mengubah tantangan yang ada menjadi peluang. Karena UMKM yang dapat bertahan adalah UMKM yang responsif terhadap perubahan sekitar dan mampu menyesuaikan diri baik dari segi produk, sistem pemasaran dan penjualan maupun penggunaan teknologi yang mendukung 
bisnis. Selain itu, perlu adanya dukungan ataupun dorongan dari pemerintah dalam mwujudkan pengembangan UMKM di tengah pandemi COVID-19. 


\section{DAFTAR PUSTAKA}

Marlinah, Lili. 2020. Peluang dan Tantangan UMKM Dalam Upaya Memperkuat Perekonomian Nasional Tahun 2020 Ditengah Pandemi Covid 19. Jurnal Ekonomi, 22, 118-121.

scribd.com. (2016, 28 Maret). Makalah UMKM.docx. Diakses pada 6 Desember 2020, dari https://www.scribd.com/doc/306156930/Makalah-UMKMdocx\#

pendidikan.co.id. (2020, 19 Oktober). UMKM: Pengertian, Ciri, Kriteria, Jenis, Contoh Lengkap. Diakses pada 6 Desember 2020, dari https://pendidikan.co.id/pengertian-umkm/

dosenpendidikan.co.id. (2020, 7 Juli). Tujuan UMKM: Jenis, Ciri, Kriteria, Karakteristik dan Pengertian. Diakses pada 6 Desember 2020, dari https://www.dosenpendidikan.co.id/tujuan-umkm/

www.online-pajak.com. (2020, 24 Juni). Peran UMKM di Indonesia yang Perlu Anda Ketahui. Diakses pada 7 Desember 2020, dari https://www.onlinepajak.com/seputar-pph-final/peran-

umkm\#: :text=Peran\%20UMKM\%20untuk\%20Mengurangi\%20Kemisk inan,berkurangnya $\% 20$ angka\%20pengangguran\%20di\%20Indonesia.\&te $\mathrm{xt}=$ Misal\%20dari\%20tahun\%202018\%2C\%20UMKM,kerja\%20hingga $\% 20120 \% 20$ jutaan\%20orang

economy.okezone.com. (2020, 19 Mei). Tantangan Besar UMKM di Tengah Covid-19. Diakses pada 7 Desember 2020, dari https://economy.okezone.com/read/2020/05/19/320/2216657/tantanganbesar-umkm-di-tengah-covid-19

radarsolo.jawapos.com. (2020, 17 September). Peluang dan Tantangan UMKM di Tengah Tekanan Pandemi Covid-19. Diakses pada 7 Desember 2020, dari 
https://radarsolo.jawapos.com/read/2020/09/17/214411/peluang-dantantangan-umkm-di-tengah-tekanan-pandemi-covid-19 